75 巻 757 号 $(2009-9)$

光重合型コンポジットレジンの衝撃引張り破壊計測*

\author{
新川和夫*1, 加藤 大 $^{* 2}$, 馬田俊雄 ${ }^{* 1}$
}

\title{
Fracture Measurement of a Light Cure Composite Resin under Impact Tensile Loading
}

\author{
Kazuo ARAKAWA ${ }^{* 3}$, Masaru KATO and Toshio MADA \\ ${ }^{* 3}$ Research Institute for Applied Mechanics, Kyushu University, \\ 6-1 Kasuga-koen, Kasuga-shi, Fukuoka, 816-8580 Japan
}

\begin{abstract}
The fracture behavior of a light cure composite resin under impact tensile loading was studied using single-edge-cracked specimens. The impact load and displacement were measured with a Piezo sensor and a high-speed extensometer, respectively. The load and displacement diagram, i.e. the external work applied to the specimen was partitioned into three parts : the elastic energy left in the fractured specimen, the nonelastic energy due to viscoplastic deformation and the fracture energy for creating new surfaces. These energies were then determined and correlated with the fracture load. Energy release rates were also evaluated, and the results were discussed.
\end{abstract}

Key Words : High Polymer Material, Light Cure Composite Resin, Impact Load, Fracture Energy, Elastic Energy, Nonelastic Energy, Fracture Load, External Work, High-Speed Extensometer

\section{1. 啨}

光重合型コンポジットレジンは，近年，歯科臨床で 広く使用される修復材料となっている.これは, この材 料が従来の金属性修復材料に比べて，審美性や操作性， さらに健全歯質保全の面で利点を有しているからであ る. しかしながら強度など力学特性が十分ではなく, き 裂やはく離などの欠陥が修復箇所で発生することがあ る.このような欠陥を生じると，二次う蝕が進行するた め, より力学的信頼性の高いコンポジットレジンの開発, ならびにそれを評価するための研究が求められている. 光重合型コンポジットレジンは, 光照射により重合硬化 させるため，作製できる試験片寸法には制限がある.し たがって, 破壊勒性計測法で推奨されている試験片形状 を満足させることは容易ではない.このため, 種々の試 験片形状や試験法が提唱され，静的負荷条件下での破壊 計測がなされている ${ }^{(1)(4)}$. 一方, 通常の口腔内では，静 的ならびに衝撃的な咬合力が作用するため, 破壊挙動に 及ぼす負荷効果を解明することは重要なことである.し かしながら、コンポジットレジンの衝撃破壊実験は技術 的に容易ではなくここれまでほとんどなされていないの が現状である.

\footnotetext{
* 原稿受付 2009 年 3 月 2 日.

*1 正員, 九州大学応用力学研究所(业816-8580 春日市春日公 園 6-1)

*2 九州大学大学院総合理工学府.

E-mail:k.arakaw@riam.kyushu-u.ac.jp
}

筆者らは, 高分子材料の脆性破壊挙動に及ぼす粘性(5)

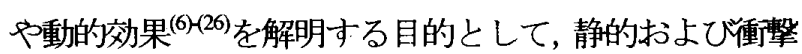

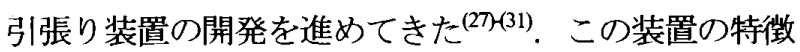
は，光ファイバを用いた変位計により，き裂近傍の静的 およひ動的変位が精度良く計測できること,これにより 粘弾性変形を含む残留変位が定量的に評価できること である.この装置を用いて,これまでに種々の高分子材 料の脆性破壊を計測し, 粘性や動的効果が脆性破壊挙動 に大きな影響を及ぼすことを示してきだ(27)-31).さらに 筆者らは，提唱した計測手法のコンポジットレジン八の 適応性を検討するため, 静的破壊実験を行った ${ }^{(32)}$.この 実験では2 枚のアクリル(PMMA)帯板間にコンポジッ トレジンを充填させた片側ノッチ付き引張り試験片を 作製した. 試験片に作用する荷重と変位より外力仕事, 破断直後の残留変位より非弾性エネルギを求めた. また 破断後の飛しょう高さより, 試験片内部に蓄積された弾 性エネルギを決定した.これらの值よりコンポジットレ ジンの破壊エネルギを求めた.さらに破面の面積を用い て, エネルギ解放率を求め, 破断荷重との対応関係を検 討した. また, PMMA 単体の圾験片との比較検討を行 い，静的破壊計測法の適応性を明らかにした.

本研究では, 前回之同様に，2枚のPMMA 帯板間に コンポジットレジンを充填させた片側ノッチ付き引張 り試験片を作製した. そして，提唱した衝揧破壊計測法 のコンポジットレジンへの適応性を検討した. 


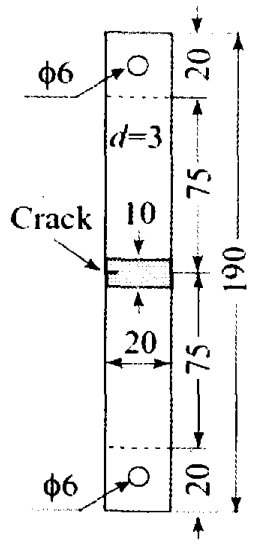

(a) Composite resin

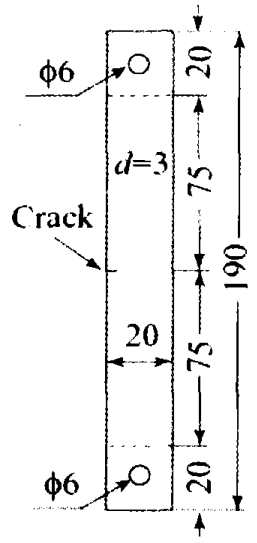

(b) PMMA
Fig. 1 Specimen geometries.

\section{2. 試瑹片およひ実験方法}

2-1 村料およひ試検片形状 光重合型コンポジッ トレジンとして,クラレメディカル(株)社製のクリアフ イルAP-Xを使用した．この材料は，歯科臨床で一般的 に使用されている修復材料である. 上述のように, 光重 合により硬化させるため, 作製できる試験片寸法には制 限がある. そのため, 本研究では, 図1 (a)に示すような 訊験片を作製した。この試験片は，2枚のPMMAの帯 板間にコンポジットレジンを充填したものであり,引張 り試験が容易となる ${ }^{(32)}$ 。ここで PMMAは，コンポジッ トレジンと比較的に材料定数が近いこと，また両者の接 着性が良好であることから採用した。

試験片の作製法を以下に示す. (1) 板厚 $3 \mathrm{~mm}$, 幅 $20 \mathrm{~mm}$, 長さ90mm のPMMA (Sumipex E) 帯板を2枚用意する. (2) 帯板の端面にボンディング刘（クリアフィルトライ エスボンド: クラレメディカル(株)製）を塗布し，光照 射器（株モリ夕 JETLITE 3000）を用いて硬化させた。 (3) 2 枚の带板を透明な平板（板厚 $5 \mathrm{~mm} の \mathrm{PMMA）上に}$ 載せ，直線になるように型枠で挟み込む。（4) 帯板の端 面間を $10 \mathrm{~mm}$ に設定し，その間にコンポジットレジンを 充填した. (5) コンポジットレジンを一様に重合させ, 試験片の反りを避けるため, 下面と上面を交互に8回 (5 秒 4 回，その後，10秒 4 回）照射した．また型枠から分 離後, コンポジットレジンの左右端を10秒照射した. (6) コンポジットレジンと.PMMAの面が同一になるように 研磨した. (7) その後, コンポジットレジンを十分に重 合させるため, 室温・大気中で24時間放置した.

試験片の片側中央部に切欠きを導入し，その先端部を カミソリで鋭くした.ただし試験片の破断荷重および外 力仕事を変化させるため, 異なる長さ2〜 7mmの切久き を導入した．さらに試験片の上下端には直径 $6 \mathrm{~mm}$ の穴 をあけ，ピン負荷用とした. また比較検討のため, 図1 (b)

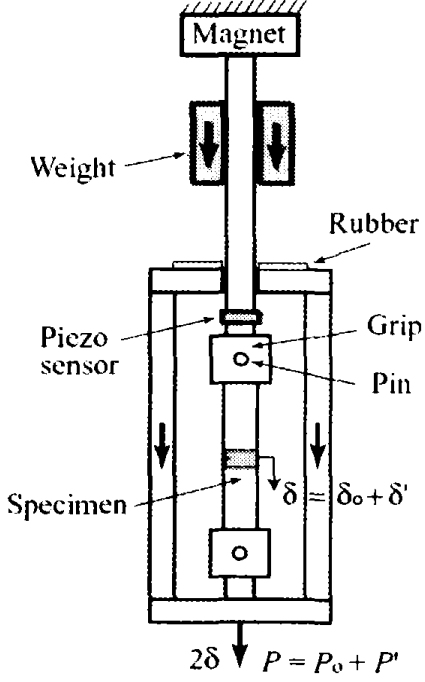

Fig. 2 Impact tensile loading method.

のような PMMA 試験片を作製した。なお以下では, 便宜上，図1 (a)をコンポジット試験片と呼ぶ.

$2 \cdot 2$ 実験方法 図 2 に衝撃引張り試験法の概略 を示す，本研究では，重鍾の自由落下を利用した衝撃

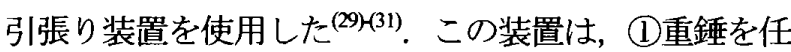
意の高さ位置で固定する電磁石，(2)試験片を固定する 軸，(3)圧縮を引張りに変換する金属枠，(4)㣫撃荷重を 計測するためのピエゾセンサから構成されている.

本研究では，重錘として質量 $10 \mathrm{~kg}$, 金属枠の上端か ら重錘までの高さを $300 \mathrm{~mm}$ とした。このとき衝撃時 の重鍾の速度は約 $2.4 \mathrm{~m} / \mathrm{s}$ となる. また金属枠の上端に 厚さ $3 \mathrm{~mm}$ のゴムシートを貼付けた。これにより衝撃 時に発生する高周波振動を軽减することができる。こ のピエゾセンサは $45 \mathrm{kHz}$ の周波数特性を有しており， 動的計測が可能である

図 3 に変位計測法の概略を示す。ここでは高速度変 位計により，き裂近傍の変位 $\delta^{\prime}$ 計測した ${ }^{(27)-(32) . こ の ~}$ 変位計では，光ファイバを試験片に貼り付け，その移 動量を PSD (Position Sensing Detector) センサで計測す る. センサからの出力波形はアンプで増幅した後，デ ジタルメモリで記録した。このセンサは約 $100 \mathrm{kHz}$ の 応答速度を有しており，静的および動的変位計測に使

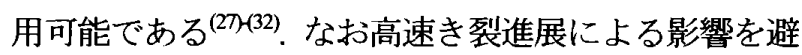
けるため, 光ファイバを切欠きから $2 \mathrm{~mm}$ 離れた上部 に貼り付けた．ただしこれによる変位の計測誤差は 数\%以下であり，実験解析では無視することとした.

\section{3. 実玫結果}

図 2 の衝撃引張り試験機を用いると, 試験片には静 的な初期荷重 $P_{\mathrm{o}}(=0.13 \mathrm{kN})$ が作用し，そのあと衝撃 


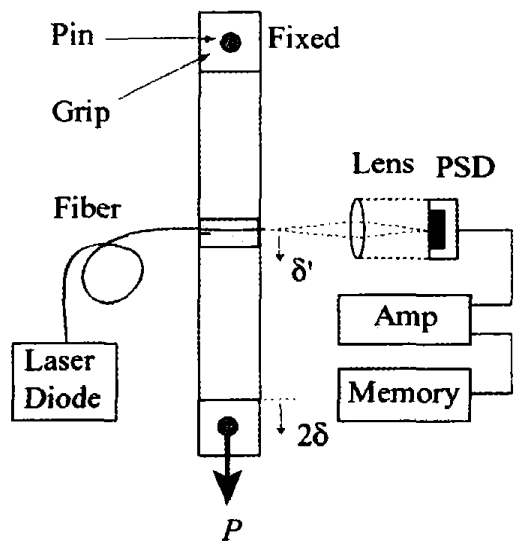

Fig. 3 Displacement measurement by PSD.

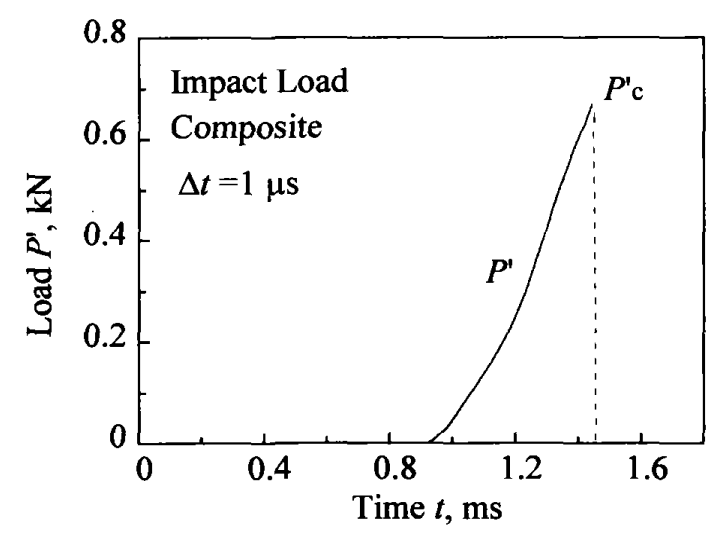

Fig. 4 Dynamic load $P^{\prime}$ versus time $t$.

荷重 $P$ が作用する，変位 $\delta$ 同様に，初期変位 $\delta_{0}$ と動 的変位 $\delta^{\prime}$ に分けられる. 図 4 に $\boldsymbol{P}^{\prime}$ と時間 $\boldsymbol{t}$ の関係を示す. $P^{\prime}$ は $t$ とともに増加し, 試験片が破断すると $P_{\mathrm{c}}^{\prime}$ から急 激に低下した。この $P^{\prime}-t$ 波形から明らかなことは，金 属枠の上端に貼付けたゴムシートにより，衝撃時に発 生する高周波振動が軽减できたことである.

図 5 に高速度変位計で測定した動的変位 $\delta^{\prime}$ と時間 $t$ の関係を示寸. $\delta^{\prime}$ は $t$ とともに増加し， $\delta_{\mathrm{c}}^{\prime}$ で急激に低下 した. そして， $\delta^{\prime}$ はその後，减衰を伴いながら振動し た. もし大きな非弾性変形が存在するならば, 振動中 心は上側へシフトするはずである．しかし明確なシフ トはみられない. すなわちこの結果は, 衝揧負荷の場 合には，非弾性変形が小さな值となることを示唆して いる. なお同様な結果が他の脆性的な高分子材料でも 得られている ${ }^{(30)(31)}$.

衝撃引張り条件下での $P^{\prime}-\delta^{\prime}$ 関係を図 4 と 5 の結果 から求めた。 そのP'- $\delta^{\prime}$ 関係を図 6 に示す。ここで示さ れていることは, P妿醇と共にほぼ直線的に増加してい

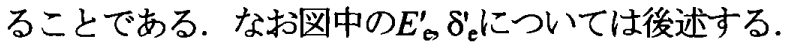

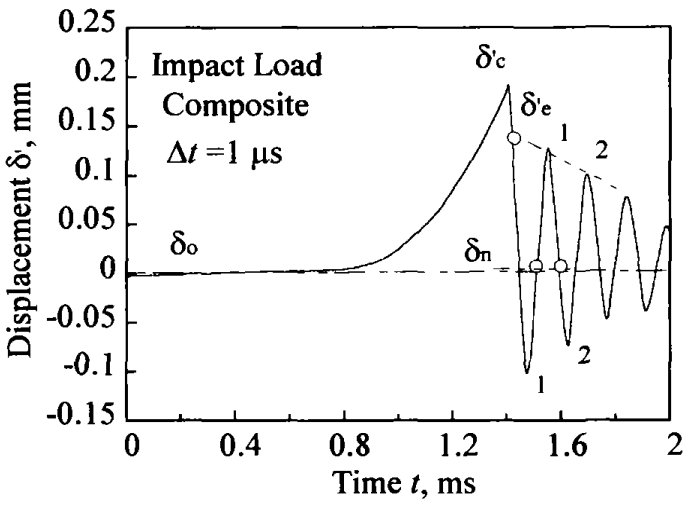

Fig. 5 Dynamic displacement $\delta^{\prime}$ versus time $t$.

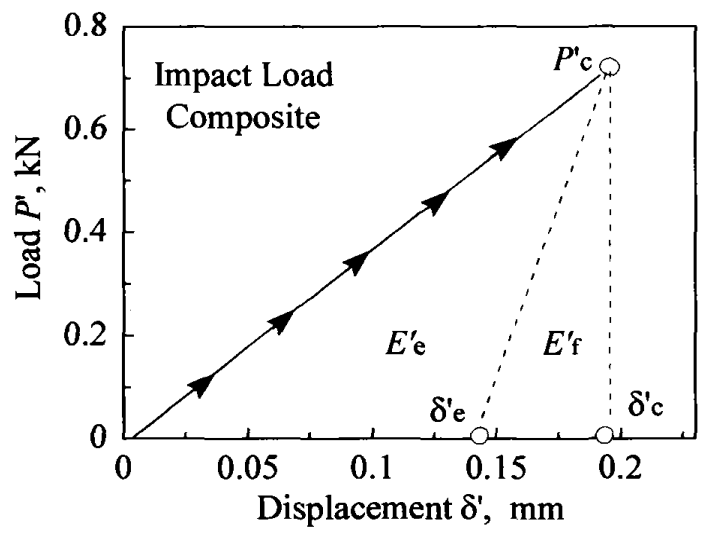

Fig. 6 Dynamic load $P^{\prime}$ versus displacement $\delta^{\prime}$.

\section{4. 破䡖エネルギ解析}

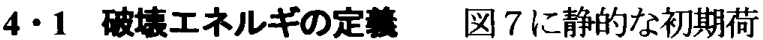
重 $P_{\mathrm{o}}$ が作用し，そのあと衝撃負荷 $P$ ぞ作用する場合の

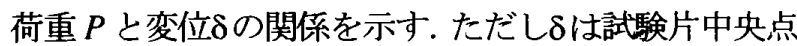

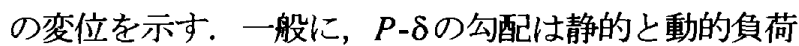
では異なっている. しかし本研究では, $P_{\mathrm{o}}$ が $P_{\mathrm{c}}$ より十 分小さい場合には大きな誤差が生じないものと仮定し 両者の公配を同一とした。このとき，外力が試験片の 半分になす仕事，才なわち外力仕事 $U_{\mathrm{ex}}$ は次式で与え られる。

$$
U_{\mathrm{ex}}=\frac{P_{\mathrm{c}} \delta_{\mathrm{c}}}{2}=\frac{\delta_{\mathrm{c}}^{\prime}\left(P_{\mathrm{o}}+P_{\mathrm{c}}^{\prime}\right)^{2}}{2 P_{\mathrm{c}}^{\prime}}
$$

ここで, $P_{\mathrm{c}}=P_{\mathrm{o}}+P_{\mathrm{c}}^{\prime}, \delta_{\mathrm{c}}=\delta_{\mathrm{c}}^{\prime} P_{\mathrm{c}} / P_{\mathrm{c}}^{\prime}$ である.

本研究では,破壊変形のプロセスが，一般的に，き裂 の進展, 試験片の破断, それに伴う弾性変形, 最後に 非弾性変形の残留という順序で生じるものと考える. そして, $U_{\mathrm{ex}}$ が図 7 に示されるように以下の 3 つのエネ ルギ成分に分離できるものと仮定した(27)(29). 


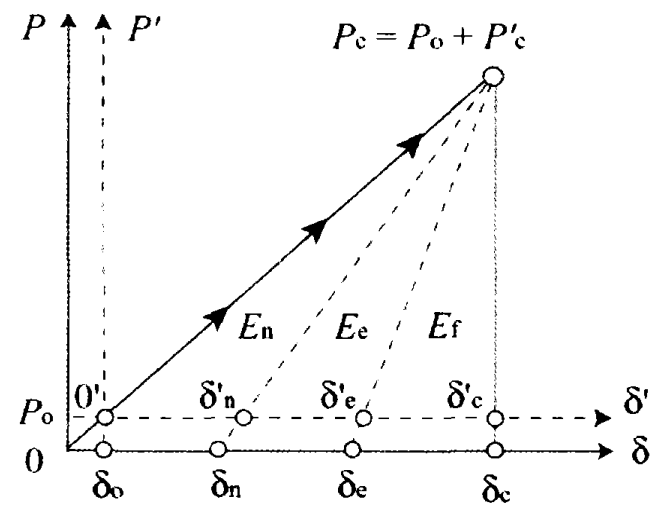

Fig. 7 Load $P$ versus displacement $\delta$ with initial load $P_{\mathrm{o}}$.

$$
U_{\mathrm{ex}}=E_{\mathrm{f}}+E_{\mathrm{e}}+E_{\mathrm{n}}
$$

ここで $E_{\mathrm{f}}$ は全破壊エネルギの半分を表わす.すなわち $E_{\mathrm{f}}$ は，破面 $\left(2 A_{\mathrm{s}}\right)$ の形成に必要な表面エネルギ，き裂か ら放出される音響エネルギ，き裂周辺の温度上昇に寄 与する熱エネルギなど非可逆的な総エネルギの半分に 対応する. 一方, $E_{\mathrm{e}}$ は試験片に蓄積される弾性的なひ ずみエネルギ， $E_{\mathrm{n}}$ は粘性や塑性ひずみなど破断後も試 験片に残留寸る非弾性的なエネルギに相当する.

本研究では, 弾性エネルギ $E_{\mathrm{e}}$, 非弾性エネルギ $E_{\mathrm{n}}$ を評価するため, 以下のことを仮定した. (1) $E_{\mathrm{e}}$ は試験 片が破断すると全て運動エネルギに変換する. (2)動的 破壊で生じる除荷過程では粘弾性効果が無視できる ${ }^{(2))}$. 寸なわち, $P_{\mathrm{c}}$ から破断直後の全変位 $\delta_{\mathrm{e}}$ や残留変位 $\delta_{\mathrm{n}}$ 一 の変化が弹性的とする(図 7 参照). (3)その結果,次式が 成立する.

$$
\begin{aligned}
& \frac{E_{\mathrm{e}}}{U_{\mathrm{ex}}}=\frac{\left(\delta_{\mathrm{e}}-\delta_{\mathrm{n}}\right)}{\delta_{\mathrm{c}}} \\
& \frac{E_{\mathrm{n}}}{U_{\mathrm{ex}}}=\frac{\delta_{\mathrm{n}}}{\delta_{\mathrm{c}}}
\end{aligned}
$$

静的負荷条件下おいてコンポジット試験片の $E_{\mathrm{e}} / U_{\mathrm{ex}}$, $E_{\mathrm{n}} / U_{\mathrm{ex}}$ 值を計測した ${ }^{(32)}$. その結果, $E_{\mathrm{e}} / U_{\mathrm{ex}}, E_{\mathrm{n}} / U_{\mathrm{ex}}$ 值 は，破断荷重と共に変化するものの，それぞれの平均 值として約 $20 \%$ と約 $48 \%$ が得られている.

$4 \cdot 2$ 非弾性エネルギ $E_{\mathrm{n}} \quad$ 非弾性エネルギ $E_{\mathrm{n}}$ を 決定するためには破断直後の試験片の残留変位 $\delta_{\mathrm{n}}$ を計 測することが必要である.この計測には前述の PSD セ ンサを応用し, 破断值後のき裂近傍の変位 $\delta^{\prime}$ を求めた (図 3 参照). 衝撃負荷での $\delta_{n}$ 值は以下のように決定し た. 図 5 の $\delta^{\prime}-t$ 波形で明らかなことは，破断直後の振動 中心 $\left(\delta_{\mathrm{n}}\right.$ で表示)が静的な初期変位 $\delta_{\mathrm{o}}(=0.05 \mathrm{~mm})$ とほぼ同

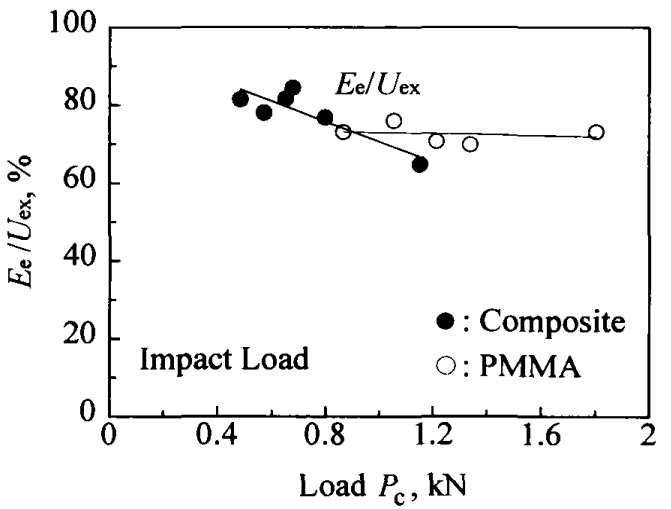

Fig. 8 Energy ratio $E_{\mathrm{e}} / U_{\mathrm{ex}}$ as a function of fracture load $P_{\mathrm{c}}$.

様となっている.この結果は, 破断後の振動中心が初 期荷重がない $P=0$ での值に近いこと，すなわち非弾性 変形が十分小さな值であることを意味している. 同様 な結果は他の試験片でも得られた. そのため衝撃負荷 条件下では $E_{\mathrm{n}}=0$ を仮定した。

$4 \cdot 3$ 弾性エネルギ $E_{0}$ 衝撃負荷装置では，破断 時の試験片の運動エネルギを直接計測することは容易 ではない.このため本研究では, 弾性エネルギ $E_{\mathrm{e}}$ を以 下の方法で評価した(図 5参照). (1)試験片の破断後の 変位波形 $\delta^{\prime}$ 加 1 周期目と 2 周期目の振幅を求める. (2)1,2 周期目の振幅から減衰を考慮した直線 (破線で表 示）を決定する. ただしこの減衰は, 負荷軸への応力 波の伝ぱによるものとする. (3)振幅を結ぶ直線と変位 曲線 $\delta^{\prime}$ との交点 $\delta_{\mathrm{e}}^{\prime}$ を求める. (4)そして, $\delta_{\mathrm{e}}$ は次式で求 めた(図 7 参照).

$$
\delta_{\mathrm{e}}=\frac{\delta_{\mathrm{e}}^{\prime}\left(P_{\mathrm{o}}+P_{\mathrm{c}}^{\prime}\right)}{P_{\mathrm{c}}^{\prime}}
$$

さらに $E_{\mathrm{e}}$ 值は, 得られた $\delta_{\mathrm{e}}$ を式(3)に代入して求めた。

図8に式(4)より求めた $E_{\mathrm{e}}$ 值を示す。ここでは $E_{\mathrm{e}}$ と 外力仕事の比 $E_{\mathrm{e}} / U_{\mathrm{ex}}$ を破断荷重 $P_{\mathrm{c}}$ の関数として表示し た. なおこの結果は, 異なる初期切欠き長さを有する コンポジット試験片 6 本, PMMA試験片 5 本から得ら れたものである. ただし, コンポジット試験片では, 負荷後に界面はく離やき裂が存在したものはデータか ら除外した. コンポジット試験片の $E_{\mathrm{e}} / U_{\mathrm{e}}$ 值にはバラツ キが存在したものの， $P_{\mathrm{c}}$ が小さいところでは約 $81 \%$, 比 較的高いところでは約 $64 \%$ 得られており， $P_{\mathrm{c}}$ と共に減 少することが示されている. 一方, PMMAの $E_{\mathrm{e}} / U_{\mathrm{ex}}$ 值は 約 $73 \%$ の定值を示した. これらの両材料での動的な $E_{\mathrm{e}} / U_{\mathrm{ex}}$ 值は, 静的負荷の場合と比べて, かなり大きな值 となっている(32). 


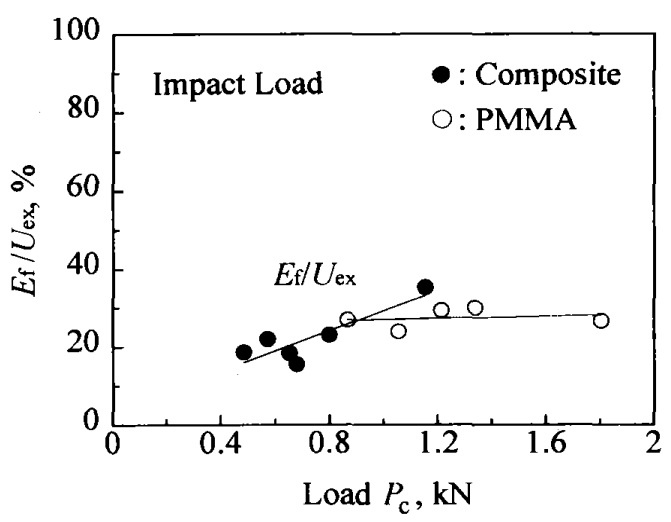

Fig. 9 Energy ratio $E_{\mathrm{f}} / U_{\mathrm{ex}}$ as a function of fracture load $P_{\mathrm{c}}$.

$4 \cdot 4$ 破壊エネルギ $E_{\mathrm{f}}$ 得られた外力仕事 $U_{\mathrm{ex}}$, 弹性 エネルギ $E_{\mathrm{e}}$, 非弾性エネルギ $E_{\mathrm{n}}=0$ を式 (2)に代入するこ とにより $E_{\mathrm{f}}$ 值を求めた. その結果を図 9 に示寸。ここ では $E_{\mathrm{f}}$ と外力仕事の比 $E_{\mathrm{f}} / U_{\mathrm{ex}}$ を破断荷重 $P_{\mathrm{c}}$ の関数として 表示した.コンポジット試験片の $E_{\mathrm{f}} / U_{\mathrm{ex}}$ 值は $P_{\mathrm{c}}$ が小さい ところでは約 $19 \%$, 比較的高いところでは約 $35 \%$ を示し た.一方, PMMAのE $E_{\mathrm{f}} / U_{\mathrm{ex}}$ 值は, 約 $27 \%$ の一定值を示 した. これらの両材料での動的な $E_{\mathrm{f}} / U_{\mathrm{ex}}$ 值は, 静的負荷 の場合と比べて，若干小さな值となっている(32).

4 -5 エネルギ解放率 $G_{\mathrm{q}}$ エネルギ解放率は，一般 的に外力仕事 $U_{\mathrm{ex}}$ を破面の面積 $A_{\mathrm{s}}$ で割ることにより求 められている. しかしながら静的負荷条件下で行った コンポジット試験片の場合には，破面形成に值接的に 寄与しない弾性エネルギ $E_{\mathrm{e}}$ と非弾性エネルギ $E_{\mathrm{n}}$ が比 較的に大きくなることが示されている( ${ }^{(32)}$. したがって, $U_{\mathrm{ex}} / A_{\mathrm{s}}$ でエネルギ解放率を求めると過大に評価される こととなる. 本研究では, 静的負荷の場合と同様に, 破 面形成に寄与寸る破壊エネルギ $E_{\mathrm{f}}$ を式 (2) で求めるこ とにより，エネルギ解放率 $G_{\mathrm{f}}$ を次式で評価した ${ }^{(32)}$.

$$
G_{\mathrm{f}}=E_{\mathrm{f}} / A_{\mathrm{s}}
$$

図10に式(5)から導かれた $G_{\mathrm{f}}$ 值を示寸。両材料にお いて， $G_{\mathrm{f}}$ は一定值でなく， $P_{\mathrm{c}}$ とともに増加した。この $G_{\mathrm{f}}$ と $P_{\mathrm{c}}$ の関係は, 脆性高分子材料における動的応力拡 大係数とき裂速度の関係 ${ }^{(20)}$ と定性的に一致する.すなお ち図10の結果は, 各試験片におけるき裂速度が同一では なく, $P_{\mathrm{c}}$ の増加に伴い，き裂速度が大きくなっているこ とを示唆している.なお両材料では $G_{\mathrm{f}}$ 異なる増加傾向 が得られている.これは，本研究で提案する試験片形状 と計測法を用いることにより，重撃下におけるコンポジ ットレジンのエネルギ解放率が定量的に評価できるこ とを示唆している. 図10におけるコンポジットレジンの $G_{f}$ 值は, 静的負荷の場合と比べて, 小さくなっており，

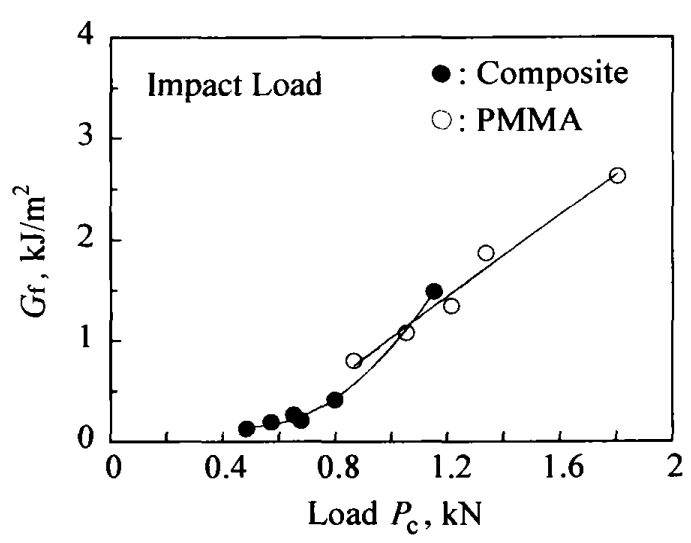

Fig. 10 Energy release rate $G_{\mathrm{f}}$ as a function of fracture load $P_{\mathrm{c}}$

他の脆性高分子材料と定性的に同様な結果が得られて いる(30),(31).

\section{5. 結 害}

2 枚のPMMA帯板間にコンポジットレジンを充填さ せた片側ノッチ付き引張り試験片を作製した。 そして, 開発した衝撃引張り計測法の適応性を検討した. 試験片 に作用寸る荷重と変位より外力仕事 $U_{\mathrm{ex}}$, 破断直後の変

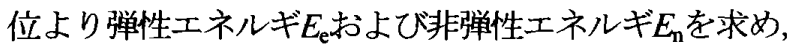
破壊エネルギ $E_{\mathrm{f}}$ を評価した。 さらに破面の面積 $A_{\mathrm{s}}$ を用 いて，エネルギ解放率を $G_{\mathrm{f}}=E_{\mathrm{f}} / A_{\mathrm{s}}$ で求め, 破断荷重 $P_{\mathrm{c}}$ との対応関係を調べた．またPMMA試験片と比較検討 した. そして以下の結果を得た.

（1）衝撃負荷では, コンポジットおよびPMMA試験片 の $E_{\mathrm{n}}$ 值はほぼ零となった。

（2）コンポジット試験片の $E_{\mathrm{e}} / U_{\mathrm{ex}}$ 值は， $P_{\mathrm{c}}$ が小さいと ころでは約 $81 \%$, 比較的高いところで約 $64 \%$ 示した. 一方, PMMAでは約 $73 \%$ の一定值を示した.

（3）コンポジット試験片の $E_{\mathrm{f}} / U_{\mathrm{ex}}$ 值は， $P_{\mathrm{c}}$ が小さいとこ ろでは約 $19 \%$, 比較的高いところで約35\%を示した。 -・ 方, PMMAでは約 $27 \% の 一$ 一定值を示した.

(4) コンポジットおよびPMMA 試験片の $G_{\mathrm{f}}$ 値は $P_{\mathrm{c}}$ と ともに増加した。 しかし両材料では，異なる増加傾向が みられた。

（5）提唱した試験片形状および衝撃引張り装置を応 用して，コンポジットレジンの $G_{\mathrm{f}}$ 值を評価することが 可能である.

本研究を行うに当たり，クラレメディカル(株)より コンポジットレジン等の実験材料を提供して頂いた. また，同社歯科材料開発部の山口里志氏，高畑裕祐氏 よりコンポジットレジンの使用方法についての助言を 頂いた，な㧍研究費の一部として，文部科学省教育研 究特別経費研究推進 (大学間連携)生体バイオマテリア 
ル高機能インターフェイス科学推進事業から補助を頂 いた。 記して謝意を表す。

\section{文䓟}

1) Kovarik, R.E., Ergle, J.W. and Fairhurst, C.W.: Dental Materials, Vol. 7 (1991) pp. 166-169.

2) Higo, Y., Damri, D., Nunomura, S., Kumada, K., Sawa, N., Hanaoka, K., Teranaka, T. and Iwamoto, T.: Bio-Medical Materials and Engineering, Vol. 1 (1991) pp. 223-231.

3) Indrani, D.J., Cook, W.D., Televantos, F., Tyas, M.J. and Harcourt, K.: Dental Materials, Vol. 11 (1995) pp.201-207.

4) Knobloch, L.A., Kerby, R.E., Seghi, R., Berlin, J.S., Clelland, N.: The Journal of Prosthetic Dentistry, Vol. 88, No. 3 (2002) pp. 307-313.

5) Williams, J.G: Fracture Mechanics of Polymers, Ellis Horwood Limited, (1984).

6) Kobayashi, A.S.: Handbook on Experimental Mechanics, Prentice-Hall, Inc., New Jersey (1987).

7) Ravi-Chandar, K.: Physical Aspects of Fracture, Bouchaud, E. et al. editors, Kluwer Academic Publisher, Netherlands, (2001) pp. 323-342.

8) Kobayashi, T. and Dally, J.W.: Fast Fracture and Crack Arrest, Hahn, GT. and Kanninen, M.F., editors, ASTM STP, Vol. 627 (1977) pp. 257-273.

9) Dally, J.W. and Shukla, A.: Eng. Fract. Mech., Vol. 13 (1980) pp. 807-817.

10) Shukla, A. and Nigam, H.: Eng. Fract. Mech., Vol. 25 (1986) pp. 91-102.

11) Kobayashi, A.S., Ramulu, M., Dadkhah, M.S., Yang, K.-H., and Kang, B.S.J.: Int. J. Fract., Vol. 30 (1986) pp. 275-285.

12) Dally, J.W., Agarwal, R.K. and Sanford, R.J.: Exp. Mech., Vol. 30 (1990) pp. 177-183.

13) Theocaris, P.S. and Papadopoulos, GA.: Eng. Fract. Mech., Vol. 13 (1980) pp. 683-698.

14) Kalthoff, J.F.: Workshop on Dynamic Fracture, Knauss, W.G editor, Califomia Institute of Technology, Pasadena (1983) pp. 11-35.
15) Knauss, W.G and Ravi-Chandar, K.: Int. J. Fract., Vol. 27 (1985) pp. 127-143.

16) Takahashi, K. and Arakawa, K.: Exp. Mech., Vol. 27 (1987) pp. 195-200.

17) Katsamanis, F.G and Delides, C.G: J. Phys. D: Appl. Phys., Vol. 21 (1988) pp. 79-86.

18) Suzuki, S., Homma, H. and Kusaka, R.: J. Mech. Phys. Solids, Vol. 36 (1988) pp. 631-653.

19) Nishioka, T., Murakami, T., Uchiyama, H., Sakakura, K. and Kittaka, H.: Eng. Fract. Mech., Vol. 39 (1991) pp. 757-767.

20) Arakawa, K. and Takahashi, K.: Int. J. Fract., Vol. 48 (1991) pp. 103-114.

21) Arakawa, K. and Takahashi, K.: Int. J. Fract., Vol. 48 (1991) pp. 245-259.

22) Arakawa, K., Nagoh, D. and Takahashi, K.: Int. J. Fract., Vol. 83 (1997) pp. 305-313.

23) Arakawa, K., Nagoh, D. and Takahashi, K.: Int. J. Fract., Vol. 96 (1999) pp. 345-360.

24) Arakawa, K., Mada, T. and Takahashi, K.: Int. J. Fract., Vol. 105 (2000) pp. 311-320

25) Arakawa, K. and Mada, T.: Exp. Mech., Vol. 46 (2006) pp. 347-353.

26) Arakawa, K., and Mada, T.: Exp. Mech., Vol. 47 (2007) pp. 609-615.

27) Arakawa, K., Mada, T., Park, S.D. and Todo, M.: Polym. Test, Vol. 25 (2006) pp. 628-634.

28) Arakawa, K. and Mada, T.: Exp. Mech., Vol. 47 (2007) pp. 211-216.

29) Arakawa, K., Mada, T., Takahashi, J., Todo, M. and Ooka, S.: J. Mater. Sci., Vol. 42 (2007) pp. 8700-8706.

30) Arakawa, K., Kato, M., Mada, T., and Todo, M.: J. Mater. Sci. Japan, Vol.57 (2008) pp.374-379.

31) Arakawa, K., Kato, M. and Mada, T.: J. JSEM, Vol. 8 (2008) pp. 422-427.

32) Arakawa, K., Kato, M. and Mada, T.: Transactions of the Japan Society of Mechanical Engineers, Series A, Vol.75, No.752 (2009) pp.516-521. 